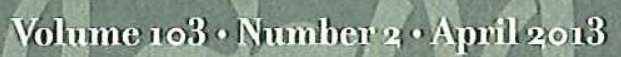

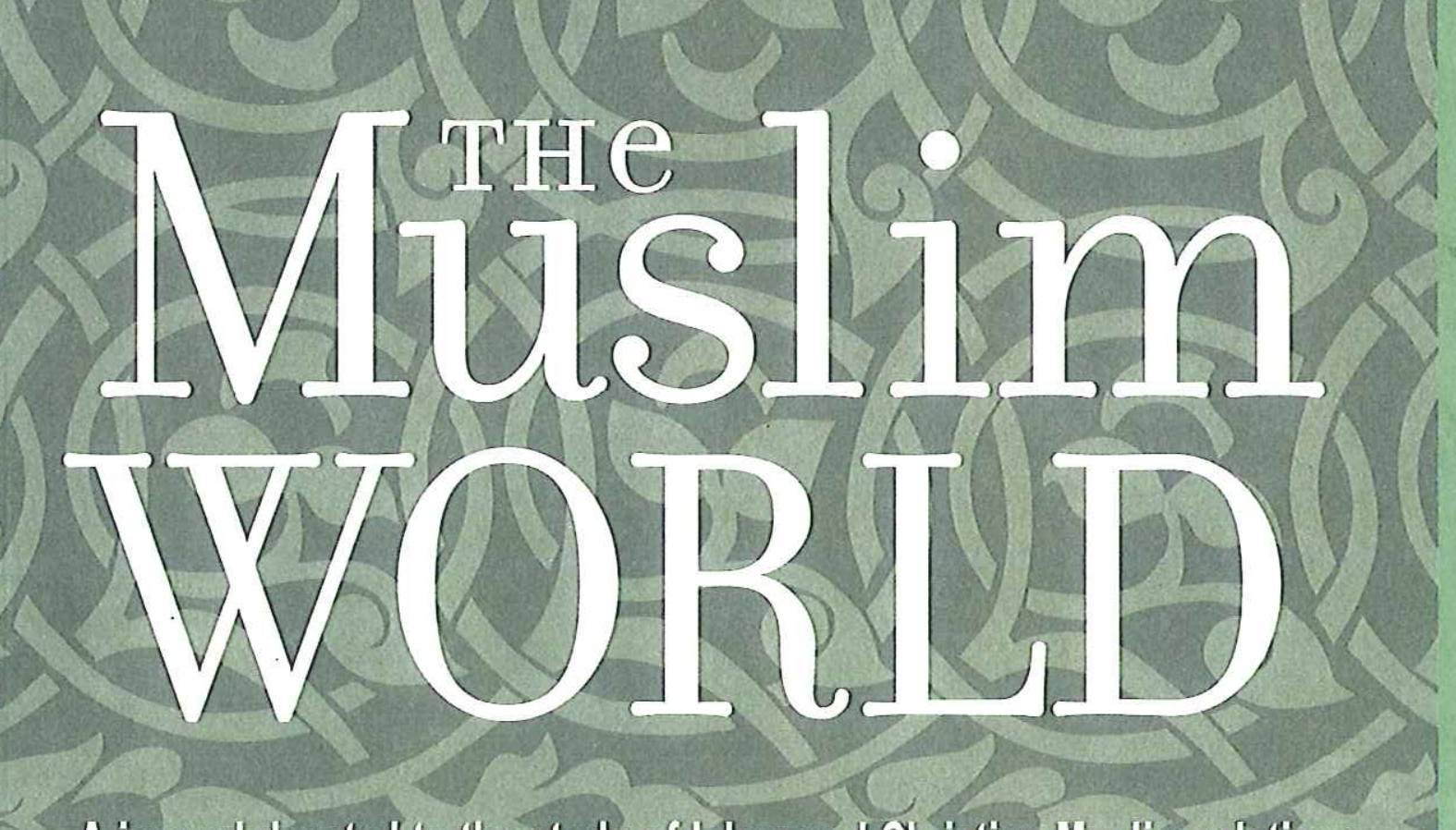

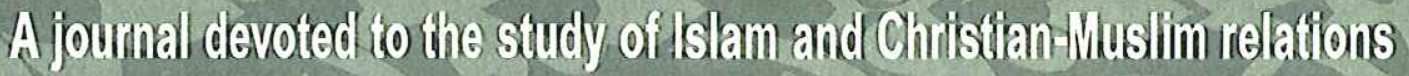

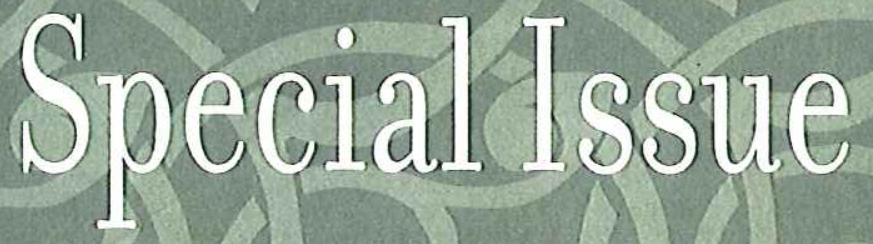

Towarr a Mlomal Comsenisus Algainst Torturire Guest IDditons

Daniticl E. R. Amriold and

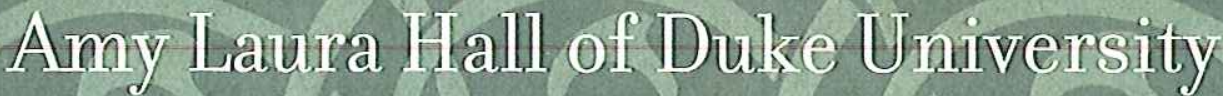




\section{Robin Kirk}

Duke University

al

he day in March, 2011, that I spoke to the assembled guests at the conference on Christian perspective on torture, I began by mentioning a special the American Christian per on the $81^{\text {st }}$ birthday of Rabbi Marshall T. Meyer, one of anniversary. We convened on the my human rights and faith heroes. His Rights Archives. ${ }^{1}$

Born in New York, Meyer studied at Dartmouth then completed his rabbinical studies at the Jewish Theological Seminary. There, one of his professors was Rabbi Abraham Joshua Heschel, a leading Jewish theologian who saw the teachings of the Hebrew prophets as a clarion call for activism on human and civil rights. After marching with the Rev. Martin Luther King, Jr., Heschel famously said, "When I marched in Selma, my legs were praying."

Meyer made "praying with his feet" a central goal of his practice as a faith leader and as a man. His first position was as assistant rabbi at a small congregation in Buenos Aires, Argentina, after he was ordained in 1958. His leadership was transformative, creating a vibrant Conservative Jewish community and founding a rabbinical school that remains to this day.

But that's not why most people remember him. Rabbi Meyer became a vocal and persistent critic of the military junta that seized the government in 1976. Between 1976 and 1982, he tirelessly worked to save the lives of thousands of Argentines - Jews and gentiles, atheists, students, trade unionists, journalists - from the murderous and largely clandestine extermination campaigns of the security forces.

One of the people whose life he saved was Jacobo Timerman, editor and publisher of the daily La Opinión. Timerman later wrote a famous book about his arrest, torture and solitary confinement at the hands of the military, Prisoner without a Name, Cell without a Number. ${ }^{2}$ The book is dedicated to Rabbi Meyer. Rabbi Meyer joined the

${ }^{1}$ For all material related to Marshall Meyer, please see: http://library.duke.edu/rubenstein/findingaids/ meyermarshall/.

${ }^{2}$ J. Timerman, Prisoner without a Name, Cell without a Number: Trans. T. Talbot (Madison: University of Wisconsin Press, 2002).

(1) 2013 Hartford Seminary

DOI: $10.1111 /$ muwo. 12007 
Argentine National Commission on Disappeared Persons and was later awarded The Order of the Liberator San Martín by the first democratically-elected president after the military junta, Raúl Alfonsín.

For Meyer, his commitment to human rights came directly out of his faith. He was committed as a Jew, as a leader of a faith community and as a human being. For him, the roots of human rights lay in what he termed "deeds of loving kindness." This was the right of every individual to be treated with love and fairness by others, and the obligation all of us have to be the keepers of our brothers and sisters. In the face of injustice, Rabbi Meyer wrote, "I have no right to be silent."

I started with Meyer's legacy because his example was and remains a very telling one for people of faith communities thinking about human rights. Marshall never wanted to be called a hero. He didn't want his extraordinary acts to be put up as an example of out of the ordinary behavior. He believed deeply that regard for your fellow human, those acts of loving kindness, should be accessible to all of us. And not just accessible normal and every day, a little like praying with your feet. Those are acts of worship even as they are entirely ordinary. In one of his sermons, "No one is born a hero, but ...,"
Marshall wrote:

\begin{abstract}
If there is one lesson to be learned from the Argentine drama it is that silence is the most important ally of those who would destroy the fabric of a society. The extremists of either the left or the right - in the final analysis I see little difference between them — count on the fear they have carefully planted within the populace of a country. Silent acquiescence ultimately explains how a beautiful country like Argentina, how a glorious city like Buenos Aires, can become a cemetery filled with anonymous mass graves. It is too easy to say that not everyone is a hero. Any individual with a modicum of intelligence is frightened in the face of death. What differentiates the activist from the coward is not the presence or absence of fear, but rather that the activist forces himself or herself to action in spite of fear while the coward allows fear to paralyze him or herself. ${ }^{3}$
\end{abstract}

"Few are guilty, but all are responsible," Meyer's teacher, Rabbi Heschel, might have added. Certainly, this conference qualifies as an act of praying with our feet, of taking this faith tradition to the hard question of what a society like ours founded on rights and the common good, can so easily and quickly pick up the darks tools of torture in the wake of a brutal attack, in this case the destruction of the World Trade Center and attack on the Pentagon on September 11, 2001.

We individually, as Americans, are not guilty of torture. But we are responsible for the actions of our nation and must use our feet and our voices to speak out in defense of those subjected to this vile human rights abuse.

\footnotetext{
${ }^{3}$ M. T. Meyer, You Are My Witness: The Living Words of Rabbi Marshall T. Meyer: J. Isay, ed. (New York:
Macmillan, 2004), 160.
} 230 
was later awarded :cted president after

of his faith. He was being. For him, the ness." This was the i, and the obligation e of injustice, Rabbi

Is a very telling one all never wanted to ; an example of out llow human, those : just accessible ts of worship even a a hero, but ...,"

silence is the society. The le difference he populace country like netery filled ; a hero. Any death. What ence of fear, of fear while

;chel, might have sur feet, of taking ded on rights and ; of torture in the Center and attack

e responsible for ı out in defense

say, ed. (New York: 2013 Hartford Seminary.
What do we consider torture? We can read the definition in "The Convention against Torture and Other Cruel, Inhuman or Degrading Treatment or Punishment" (1984) ${ }^{4}$ as a starting point:

any act by which severe pain or suffering, whether physical or mental, is intentionally inflicted on a person for such purposes as obtaining from him or a third person information or a confession, punishing him for an act he or a third person has committed or is suspected of having committed, or intimidating or coercing him or a third person, or for any reason based on discrimination of any kind, when such pain or suffering is inflicted by or at the instigation of or with the consent or acquiescence of a public official or other person acting in an official capacity. It does not include pain or suffering arising only from, inherent in or incidental to lawful sanctions.

It is important to go to the law on this as a way of highlighting a couple of things. First, there is nothing that restricts the definition of torture to a political context. Torture occurs when one person intentionally inflicts severe pain or suffering upon another to get something, with the approval or participation of a public official. I always emphasize to my students that most of the torture that takes place in the world has nothing to do with what is usually considered politics. When someone is suspected of being a pickpocket, they are tortured. If a marcher is detained, they are tortured. A suspected car thief is tortured within minutes of being brought into a police station.

This was certainly part of the drama taking place in my native Chicago recently. As recent court cases laid bare, between 1972 and 1991 approximately 135 African-American men and women were arrested and tortured at the hands of former Chicago Police Commander Jon Burge and officers under his command at Area 2 police headquarters. My alma mater, the University of Chicago, has a human rights center and they reported that some victims were as young as thirteen. Methods included electric shock to the ears and genitalia, mock executions, suffocation, and burning. Area 2 cases are seen by many observers as part of a pattern and practice of racially-motivated police brutality. ${ }^{5}$

To emphasize, torture can happen before any question is asked - or even if the security forces plan no questions. It is absolutely ordinary, part of the every day practice around the world. In fact, to not be tortured in many parts of the world is the anomaly.

In our prisons, torture is completely unremarkable. I'm not talking about the Hollywood-style torture of shows like "24," which glorify the abuse and make it seem like it is always, inevitably, effective. I'm referring to the torture that is prolonged solitary confinement, commonly used as a punishment for violent and non-violent offenders in our prisons. This type of torture is less graphic modes - no blood, no bruises - yet it is also one of the most cruel, and with long term and often life-altering damage to the mind.

\footnotetext{
${ }^{4}$ For background and document, see: http://untreaty.un.org/cod/avl/ha/catcidtp/catcidtp.html.

${ }^{5}$ For further information, see: http://humanrights.uchicago.edu/chicagotorture/.

O 2013 Hartford Seminary.
} 
A second point l'd like to make is about how torture is perceived in the United States in the wake of September 11. We can see that through the lens of television in particular: Human Rights First is a wonderful US-based advocacy group that has done brilliant work on this. ${ }^{6}$ They show how dramas like "24," "NYPD Blue," "Lost," and "Alias" incorporated torture into the story line.

The crucial point here, though, is not the torture itself. That's been around for a long time. What is critical is that the torture is being administered by the good guy. For instance, CIA hero Jack Bauer, played by Kiefer Sutherland, tortures the suspected terrorist in order to protect Americans. And the torture always works. It is positive, necessary, vital to the safety of our cities, homes and schools. Jane Mayer in The New Yorker wrote about this, and interviewed the producers of " 24 ," who were absolutely unapologetic. ${ }^{7}$

Human Rights First then followed up by bringing real military and FBI commanders and interrogators to meet with Hollywood professionals, to inform them about the reality of torture. Not only did these professionals, who have long studied interrogation techniques, point out that shooting someone in the kneecaps or simulating the execution of their young children — both scenes in " 24 " - would be illegal. Such techniques, they emphasized, do not work. They do not make us safer.

Some of these techniques also inspired our forces in the field. What, after all, is more "cinematic" than the dozens of photos taken in places like Abu Ghraib? According to the investigation prepared by Army Major General Antonio M. Taguba, US personnel beat prisoners, threatened them with dogs, sexually humiliated them and subjected them to mock torture sessions and executions. During these ordeals, they posed and photographed. Later interviewed by the New Yorker's Seymour Hersh, Taguba said he described to Secretary of Defense Donald Rumsfeld "a naked detainee lying on the wet floor, handcuffed, with an interrogator shoving things up his rectum, and said, 'That's not abuse. That's torture.' " Subsequently, a handful of low-ranking soldiers were convicted of crimes like dereliction of duty and aggravated, yet not a single commander or, so far, government official - faced punishment worse than demotion. ${ }^{8}$

Since, Americans have learned that their government tortured prisoners in Guantánamo and kidnapped others and sent them to secret Central Intelligence Agency "black sites" where they were tortured. Suspects - dozens since proved innocent have been kidnapped abroad (or "rendered") by so-called "snatch teams" and sent to third countries like Egypt, Jordan and Uzbekistan, all with proven records of torture.

\footnotetext{
${ }^{6}$ http://wwww.humanrightsfirst.org/our-work/law-and-security/torture-on-tv/.

7 J. Mayer, "Whatever It Takes: The Politics of the Man Behind '24,' " The New Yorker (February 19, 2007), http://www.newyorker.com/reporting/2007/02/19/070219fa_fact_mayer\#ixzz2EUKFshJa.

${ }^{8}$ S. M. Hersh, "Torture at Abu Ghraib: American Soldiers Brutalized Iraqis. How Far up Does the Responsibility Go?" The New Yorker (May 10, 2004), http://www.newyorker.com/archive/2004/05/10/ 040510fa_fact\#ixzz2EULOCM76.
}

It's not a President Ro. Convention : Punishment," States opposi world today." and for a pow that torture is

For activis one: torture is in classrooms knowledge th person. Peoplı is deliberate as accept torture

One of the Dr. Alfred Mcr funded and er applied in blac and ear cover: without sleep universities. As showed prison completely nor

Finally, I'd human rights $\mathrm{n}$ morality as a $\mathrm{d} \epsilon$ people agree $o$. all other argum

But in pract own experienc being against tc we in the hum Constitution an having left ber America, finally right not to be $t$

\footnotetext{
${ }^{9}$ A. W. McCoy, $A \subset$ York: Owl Books,
}

() 2013 Hartford Semina 
the United States sion in particular. me brilliant work ias" incorporated

rround for a long $\because$ good guy. For $s$ the suspected s. It is positive, ayer in The New were absolutely

'BI commanders about the reality sd interrogation ig the execution echniques, they

after all, is more Iccording to the personnel beat bjected them to sed and photoaguba said he ying on the wet said, 'That's not were convicted ander or, so far;

1 prisoners in igence Agency əd innocent $1 s "$ and sent to ds of torture.

ser (February 19, 2EUKFshJa.

Far up Does the live/2004/05/10/

3 Hartford Seminary.
It's not a given that a Republican Administration would favor torture. In 1984, President Ronald Reagan made the United States the 63rd nation to sign "The UN Convention against Torture and Other Cruel, Inhuman or Degrading Treatment or Punishment," declaring in his statement that ratification will "clearly express United States opposition to torture, an abhorrent practice unfortunately still prevalent in the world today." In 2004 and since, only a few Democrats have publicly opposed torture, and for a powerful reason. In poll after poll, over half of Americans support it, believing that torture is often or sometimes justified to keep us safe from terrorists.

For activists, what is crucial to extract from both of these previous points is a third one: torture is taught. Torture is a suite of techniques and processes that can be relayed in classrooms, workshops, conference rooms and lecture halls. Torture is a body of knowledge that has been passed from country to country, force to force, person to person. People teach the methodology, the thinking. It's not absorbed from the ether, but is deliberate and studied. And then that knowledge is passed to the populace, who then accept torture as normal and even desireable.

One of the great books detailing how torture is taught is A Question of Torture by Dr. Alfred McCoy. The book goes into the background of how our own government funded and encouraged studies on psychological torture. Those techniques were then applied in black sites and at places like Guantánamo. Isolation techniques - the mitts and ear covers, the lightless cells, extremes of heat or cold, days of darkness, days without sleep - have been tested and were part of research efforts at American universities. And they were and are completely public. Photograph after photograph showed prisoners hooded and mitted and shackled: torture before our very eyes and completely normalized. ${ }^{9}$

Finally, I'd like to conclude with a fourth point that is partially a self-criticism of the human rights movement, of which I consider myself a part. Often, people use the word morality as a defense against torture, assuming that this is something that of course most people agree on. It feels a bit like the ace in a card game. If you say "morality," it trumps all other arguments.

But in practice, morality is a very weak tool to use against torture. Speaking from my own experience, prior to September 11, I would have described most Americans as being against torture. I assumed - wrongly, as it turned out, that this was an argument we in the human rights community had won. Here in the United States, with our Constitution and our Bill of Rights, having passed through the civil rights movement, having left behind the support for genocidal regimes in Africa and Asia and Latin America, finally, I thought, we had come to a broad agreement that certain rights, like the right not to be tortured, were clear, obvious - that they were moral. ${ }^{9}$ A. W. McCoy, A Question of Torture: CIA Interrogation, from the Cold War to the War on Terror(New
York: Owl Books, 2006).

(0) 2013 Hartford Seminary. 
But that was not the case. This was dramatically not the case. Within days of the attack, probably within hours of the attack, talk radio was buzzing with people asking not if we should torture to get at the identity of the attackers and supporters, but how we should torture, with what techniques and with what intensity.

This was clearly reflected in the decisions taken by the Bush Administration at the time. It was vice president Dick Cheney that put it most directly. He argued that the moral position was to go to what he called "the dark side" and use torture, not "enhanced interrogation," in order to defend ourselves.

My self-criticism is that I think the human rights community didn't do enough to promote human rights within the United States. We assumed that we had won this argument. Now, we are faced with accounting for what happened between the attack and the decision by President Barack Obama to formally outlaw torture. This was the first executive order he signed after his inauguration.

But so much is left undone to this day. The hundreds of people, many of them innocent, who were tortured, have not received reparations or indeed any acknowledgement of the crime committed against them. The masterminds of $9 / 11$, who themselves were tortured, cannot be tried fairly because some of their testimonies were obtained under torture. Judging by the students in my Duke University classes - who, it might be assumed, tend toward the pro-human rights spectrum — most Americans still support torture as an unpleasant but necessary tool in our arsenal against attack.

So what arguments work against torture? We have to use them all. We have to use them effectively. And we have to pray them with our feet, we have to make them matter in whatever venue counts, whether it is in the Illinois State Legislature, the halls of Congress, the UN or your local church, synagogue or mosque. We cannot afford to be silent.

Torture is wrong; it does not make us safer; it does not work; it paves the way for further and more reprehensible torture; it stains those who practice it; it damages torture practitioners, who live with the effects for the rest of their lives. And it becomes normalized in our own police stations, jails and on the streets where people interact. Those who have tortured must be heard. That not only is justice for them; it allows us to know where, when and how torture happened, so that it may never happen again. Accountability is essential and a task that is yet unfulfilled. Arguments against torture have to be part of what we teach and preach, if we are to ever build a sturdy bulwark against a return to the "dark side."

Let me end with Rabbi Meyer and one of his sermons. Today, human rights advocates are often accused of being naive or "soft on terror." Nothing could be further from the truth. I think we are very wise to the ways of the world. We know that good people are capable of terrible things. And we know that we must give them the example and support which all of us need to uphold basic human values: our shared humanity. Rabbi Meyer faced the same sort of criticism, on the streets and even in his own congregation. In one of his sermons, "A Rabbi in Politics," he addressed this directly: 
Within days of the with people asking sorters, but how we

dministration at the gued that the moral ure, not "enhanced

lidn't do enough to t we had won this between the attack ıre. This was the first

sple, many of them ıdeed any acknowlinds of $9 / 11$, who eir testimonies were rsity classes - who, most Americans still against attack. I all. We have to use have to make them tate Legislature, the mosque. We cannot

it paves the way for it; it damages torture es. And it becomes .ere people interact. : them; it allows us to never happen again. nents against torture iild a sturdy bulwark

[oday, human rights ." Nothing could be the world. We know at we must give them c human values: our 1 , on the streets and abbi in Politics," he
Many times during the Argentine dictatorship, people asked me, 'What are you doing as a rabbi in politics?' I replied, 'what do you mean, politics?' They said, 'Well, you're involved in human rights!' Human rights in Argentina for eight years was the subversive phrase. It is true that politics and religion can be mixed in a very unhealthy fashion. When fundamentalists declare that governments should legislate religion, that is unhealthy. On the other hand, that which comes from the depth of one's being and militates in favor of the sanctity of life, that is neither religion nor politics. It is the essence of being human. ${ }^{10}$ 